\title{
Relation between concentrations of digoxin in the myocardium and in the plasma
}

\author{
ALASDAIR MALCOLM ${ }^{1}$ AND JOHN COLTART \\ From the Cardiac Department, St. Thomas's Hospital, London
}

It soon becomes apparent to those who use cardiac glycosides clinically that the relation between the amount of drug administered and the therapeutic effect is highly variable. The correlation of dose and effect of the drug is influenced by a number of factors including bioavailability, completeness of absorption, apparent volume of distribution, rate of elimination, degree of plasma protein binding, diffusion and active transport to the site of action, and local factors at the side of action (Koch-Weser, 1972; Sjöqvist and Bertilsson, 1973). KochWeser (1972) has proposed that for the great majority of drugs individual differences in response to a certain dose of a drug are primarily the result of individual differences in plasma concentration achieved, rather than of a different intensity of effect associated with the same plasma concentration. In general terms this has proved true for the digitalis glycosides, and much of the relevant evidence is reviewed by Sheiner (1974) who concludes that, 'The serum concentration of digitalis preparations bears a more consistent relationship to drug effects than do doses administered'. With the ready commercial availability of digoxin radioimmunoassay systems, plasma digoxin measurements are now often made. Antisera for the other cardiac glycosides, including digitoxin, have also been prepared. The importance of knowledge of the timing of the blood sample in relation to drug administration and of the drug's kinetic pattern (Vere, 1972; Doherty, 1973; Ewy et al., 1974) must be emphasised. Endogenous or exogenous steroids, or steroid antagonists such as spironolactone, may interfere with the radioimmunoassay if antisera of sufficient specificity are not selected (Smith and Haber, 1973; Steiness, 1974).

The interpretation of drug concentrations in plasma would be straightforward if: (1) therapeutic

${ }^{1}$ Kleinwort Research Fellow. effect depended on the drug itself and not on metabolites, (2) protein binding was minimal, (3) the concentration/response graph followed a known and readily definable form such as the linear or monoexponential, and (4) the functional state of the drug receptor responded predictably and instantaneously, or nearly so, to changes in plasma concentration. The first condition is satisfied by digoxin but the second and third conditions are only partially satisfied, and the fourth is not. The importance of the second and third points is crucial and may be illustrated by recourse to the conceptual device of mathematical modelling. The simplest practical model to consider in this situation is the two-compartment model first comprehensively described by Teorell in 1937 (Vere, 1972). Administered drug rapidly enters a 'space' where thorough mixing soon occurs (first compartment $\approx$ blood and some part of well-perfused tissues) and thereafter exchanges with a 'space' more remote from the outside world by virtue of relatively slower ingress and egress of drug across the intercompartmental boundary (second compartment $\approx$ cells and most drug receptor sites). Intercompartmental transfer is treated as a two-way flux, and absorption and elimination of the drug as one-way fluxes according to the Fick equations for simple diffusion, a valid approach simply because most drugs are effectively non-electric in their transfer behaviour. Teorell showed that very soon after full absorption of a drug, all the terms in the mathematical description of the fluxes across the various boundaries become vanishingly small except for the one-way flux of drug removal from tissue. This leaves a single exponential for removal of drug from the blood and so, unless blood volume alters, plasma concentrations of the drug should follow this exponential form (Vere, 1972). Tissue inactivation of digitalis glycosides does not occur and in this situation the tissue concentration 
curve reaches a maximum where it cuts the curve for concentration in plasma. Beyond that point the flow of drug reverses, being driven by the concentration gradient from tissue into blood. The time to plasma peak concentration is independent of the dose of drug given but the height of the peak is directly proportional to it. The half-time $\left(T_{1}\right)$ is also independent of the initial, peak, or any other concentration of the drug, being a pure function of one-rate constant in the model. It is found from the slope (k) of the final exponential part of the plasma concentration curve by:

$$
\mathrm{T}_{\mathrm{i}}=\frac{\ln 2}{\mathrm{k}}
$$

where $\ln$ is the logarithm to the base e (Vere, 1972).

The Teorell model was developed from consideration of the kinetics of free drug in plasma. When reversible protein binding occurs this effectively adds another compartment to the system. Digoxin is 23 per cent bound to plasma albumin (Lukas and De Martino, 1969) and since protein binding is not easy to simulate (Vere, 1972) this limits the accuracy of the Teorell model for the kinetic pattern of the drug.

From our consideration of some of the pharmacokinetic principles influencing the plasma concentrations of the cardiac glycosides, we now turn to look at data that have become available on their myocardial concentration. Digitalis glycosides are present in myocardial tissue in far higher concentrations than in skeletal muscle or plasma. For example, Coltart et al. (1972) found that in 8 patients undergoing mitral valve replacement, who had been on maintenance treatment with digoxin, the content in papillary muscle ranged from 15.5 to $132 \mathrm{ng} / \mathrm{g}$ (mean 77.7) and in skeletal muscle from 7.5 to $23 \mathrm{ng} / \mathrm{g}$ (mean 11.3). The ratio of myocardial digoxin concentration to plasma digoxin concentration varied between patients from 39:1 to 155:1. Doherty et al. (1967) gave ${ }^{3} \mathrm{H}$-digoxin to adults shortly before their expected time of death and found the ratio of myocardial-to-serum digoxin concentration to range from $17: 1$ to $65: 1$, with a group mean digoxin concentration in myocardial samples of $85 \mathrm{ng} / \mathrm{g}$. In patients with normal renal function digoxin concentrations were even higher in the kidney than in the myocardium, though with those in renal failure this did not occur. However, in myocardial samples devoid of fibrous tissue, Härtel et al. (1976) have shown a linear correlation between serum digoxin and papillary muscle digoxin concentrations from 12 adults undergoing mitral valve replacement, confirming an earlier similar finding by Güllner et al. (1974).

Kim et al. (1975) obtained tissue from 7 prema- ture infants, 4 full-term newborn infants, and 4 older children who had received digoxin for cardiac failure. The group mean digoxin levels in right and left ventricular samples from the premature and the full-term infants were all around $190 \mathrm{ng} / \mathrm{g}$, but in the samples from older children the group mean levels were around $70 \mathrm{ng} / \mathrm{g}$. Gorodischer et al. (1976) found the myocardial uptake of digoxin to be almost twice as great in infants as in adults at any given serum concentration. Yet children seem to be less sensitive to digitalis than adults. A definition of sensitivity includes two mechanisms: agerelated pharmacokinetic differences, and age-related differences in the drug's effect at a given concentration. Experimentally, it has been shown that the age-related pharmacokinetic differences result from a large volume of distribution of digitalis glycosides in the immature animal (Glantz et al., 1976), and also at the same drug concentration the Purkinje fibres of the young canine myocardium were less sensitive to digitalis effect than those from adult animals (Rosen et al., 1975). These findings explain the larger therapeutic dose per kilogram body weight of digitalis required in children.

Cardiac transplantation has afforded a very special opportunity to study the distribution of digoxin in the human heart because samples from the recipient's organ can be analysed with both the timing of the last digoxin dose known and a plasma sample taken after induction of anaesthesia, and before cardiopulmonary bypass. In such a study of 7 transplant recipients' hearts, Coltart et al. (1974) found no consistent relation between plasma concentrations and tissue concentrations of digoxin in samples from each of the cardiac chambers. Moreover, in the presence of diffuse histological abnormalities of the myocardium, tissue digoxin was decreased and such structural inhomogeneity seemed at least partly to account for disparities in tissue concentrations within individual hearts. Minimal general fibrosis and milder specific histological abnormalities did not alter distribution between various chambers. In 2 patients given labelled digoxin for their last dose, 4 and 5 hours before surgical removal of the heart, the ratio of labelled to total myocardial digoxin was relatively constant for all 4 cardiac chambers.

The receptor for the cardiac effects of the digitalis glycosides has not been isolated or fully characterised, but there is evidence that it is intimately linked with the enzyme sodium, potassium-activated adenosine triphosphatase $\left(\mathrm{Na}^{+}, \mathrm{K}^{+}\right.$-ATPase) (Akera et al., 1970; Besch et al., 1970; Schwartz, 1976). $\mathrm{Na}^{+}, \mathrm{K}^{+}$-ATPase is present in the microsomal fraction of human heart muscle (Coltart et al., 1974) and it has generally been found that binding 
of cardiac glycosides to the myocardium of sensitive species is mainly in the microsomal fraction (Marks, 1972; Goldman et al., 1973).

In recipients' hearts removed at cardiac transplantation, Coltart et al. (1974) found that in the presence of diffuse histological abnormalities of the myocardium, tissue digoxin concentrations were decreased, but in 3 hearts microsomal fraction digoxin concentrations in samples from various parts of the heart were uniform. Thus, the inhomogeneity of tissue digoxin concentrations in these diseased and malfunctioning hearts is not paralleled by site-to-site disparities of microsomally bound digoxin and this presumably reflects uniformity of binding to the possible receptor site. Perhaps even more interesting is the fact that the plasma digoxin concentrations at the start of operation versus left ventricular sample microsomal fraction digoxin concentrations were $1.8 \mathrm{ng} / \mathrm{ml}$ versus $1.9 \mathrm{ng} / \mathrm{mg}, 2.6 \mathrm{ng} / \mathrm{ml}$ versus $2.5 \mathrm{ng} / \mathrm{mg}$, and $1.0 \mathrm{ng} / \mathrm{ml}$ versus $1.2 \mathrm{ng} / \mathrm{mg}$ (Coltart et al., 1974). Such evidence suggests that plasma concentrations could give a better guide to digoxin concentrations at the receptor site than whole-tissue digoxin concentrations.

To conclude, it is important to emphasise that the clinical effects of the digitalis glycosides can be modified by many agents and circumstances. This variability of effect may not result solely from different plasma digoxin concentrations. The digitalis glycosides exert 'indirect' effects upon the heart by actions on the autonomic nervous system. Therapeutic doses enhance vagal tone (sinus rate slowing, atrioventricular conduction slowing, decrease in automaticity of atrial ectopic pacemakers, and decrease in refractory period of atrial muscle cells) and sensitise carotid sinus baroreceptors (at same level of blood pressure leading to increased efferent vagal activity and concomitant withdrawal of sympathetic tone), and high doses are sympathomimetic (increasing traffic in cardiac, phrenic, and peripheral sympathetic nerves) (Gillis et al., 1975; McRitchie and Vatner, 1976). Smith (1973) presents some of the evidence for alterations in individual sensitivity to cardiac glycosides according to the following other factors: plasma electrolytes (potassium, magnesium, and calcium), adequacy of tissue oxygenation, acid-base balance, age, renal function, thyroid status, other drugs used concurrently, and type and severity of the underlying heart disease. It remains to be seen how many of these factors may exert their influence by modifying the tissue concentrations and/or subcellular localisation of the glycosides.

We believe that the measurement of plasma concentrations of cardiac glycosides can provide useful guidelines in patient care. The information obtained must always be interpreted in the light of the pharmacokinetic principles which apply to this group of drugs, and with an awareness of the many factors that can modify an individual's response to them.

\section{References}

Akera, T., Larsen, F. S., and Brody, T. M. (1970). Correlation of cardiac sodium- and potassium-activated adenosine triphosphatase activity with ouabain-induced inotropic stimulation. Fournal of Pharmacology and Experimental Therapeutics, 173, 145-151.

Besch, H. R., Allen, J. C., Glick, G., and Schwartz, A. (1970). Correlation between the inotropic action of ouabain and its effects on subcellular enzyme systems from canine myocardium. Fournal of Pharmacology and Experimental Therapeutics, 171, 1-12.

Coltart, D. J., Güllner, H. G., Billingham, M., Goldman, R. H., Stinson, E. B., Kalman, S. M., and Harrison, D. C. (1974). Physiological distribution of digoxin in human heart. British Medical fournal, 4, 733-736.

Coltart, J., Howard, M., and Chamberlain, D. (1972). Myocardial and skeletal muscle concentrations of digoxin in patients on long-term therapy. British Medical fournal, 2, 318-319.

Doherty, J. E. (1973). Digitalis glycosides: pharmacokinetics and their clinical implications. Annals of Internal Medicine, 79, 229-238.

Doherty, J. E., Perkins, W. H., and Flanigan, W. J. (1967). The distribution and concentration of tritiated digoxin in human tissues. Annals of Internal Medicine, 66, 116-124.

Ewy, G. A., Marcus, F. I., Fillmore, S. J., and Matthews, N. P. (1974). Digitalis intoxication-diagnosis, management and prevention. Cardiovascular Clinics, 6 (2), 153-174.

Gillis, R. A., Pearle, D. L., and Levitt, B. (1975). Digitalis: a neuroexcitatory drug (editorial). Circulation, 52, 739-742.

Glantz, S. A., Kernoff, R., and Goldman, R. H. (1976). Age related changes in ouabain pharmacology. Circulation Research, 39, 407-414.

Goldman, R. H., Coltart, D. J., Friedman, J. P., Nola, G. T., Berke, D. K., Schweizer, E., and Harrison, D. C. (1973). The inotropic effects of digoxin in hyperkalemia: relation to $\left(\mathrm{Na}^{+}, \mathrm{K}^{+}\right)$-ATPase inhibition in the intact animal. Circulation, 48, 830-838.

Gorodischer, R., Jusko, W. J., and Yaffe, S. J. (1976). Tissue and erythrocyte distribution of digoxin in infants. Clinical Pharmacology and Therapeutics, 19, 256-263.

Güllner, H. G., Stinson, E. B., Harrison, D. C., and Kalman, S. M. (1974). Correlation of serum concentrations with heart concentrations of digoxin in human subjects. Circulation, 50, 653-655.

Härtel, G., Kyllönen, K., Merikallio, E., Ojala, K., Manninen, V., and Reissell, P. (1976). Human serum and myocardium digoxin. Clinical Pharmacology and Therapeutics, 19, 153-157.

Kim, P. W., Krasula, R. W., Soyka, L. F., and Hastreiter, A. R. (1975). Postmortem tissue digoxin concentrations in infants and children. Circulation, 52, 1128-1131.

Koch-Weser, J. (1972). Serum drug concentrations as therapeutic guides. New England fournal of Medicine, 287, 227-231.

Lukas, D. S., and De Martino, A. G. (1969). Binding of digitoxin and some related cardenolides to human plasma proteins. Fournal of Clinical Investigation, 48, 1041-1053.

McRitchie, R. J., and Vatner, S. F. (1976). The role of arterial baroreceptors in mediating the cardiovascular re- 
sponse to a cardiac glycoside in conscious dogs. Circulation, 38, 321-326.

Marks, B. H. (1972). Factors that affect the accumulation of digitalis glycosides by the heart. In Basic and Clinical Pharmacology of Digitalis, p. 69. Ed. by B. H. Marks and A. M. Weissler. Charles C Thomas, Springfield, Illinois.

Rosen, M. R., Hordof, A. J., Hodess, A. B., Verosky, M., and Vulliemoz, Y. (1975). Ouabain-induced changes in electrophysiologic properties of neonatal, young and adult canine cardiac Purkinje fibres. Fournal of Pharmacology and Experimental Therapeutics, 194, 255-263.

Schwartz, A. (1976). Is the cell membrane $\mathrm{Na}^{+}, \mathrm{K}^{+}-\mathrm{ATPase}$ enzyme system the pharmacological receptor for digitalis? Circulation Research, 39, 2-7.

Sheiner, L. B. (1974). The use of serum concentrations of digitalis for quantitative therapeutic decisions. Cardiovascular Clinics, 6 (2), 141-151.

Sjöqvist, F., and Bertilsson, L. (1973). Plasma concentrations of drugs and pharmacological response in man. In Biological
Effects of Drugs in Relation to their Plasma Concentrations, p. 25. Ed. by D. S. Davies and B. N. C. Prichard. Macmillan, London.

Smith, T. W. (1973). Digitalis glycosides. New England fournal of Medicine, 288, 942-946.

Smith, T. W., and Haber, E. (1973). Digitalis. New England fournal of Medicine, 289, 1063-1072.

Steiness, E. (1974). Renal tubular secretion of digoxin. Circulation, 50, 103-107.

Vere, D. W. (1972). The significance of blood levels of drugs. In The Scientific Basis of Medicine Annual Reviews, p. 363. Ed. by I. Gilliland and J. Francis. Athlone Press, London.

Requests for reprints to Dr. John Coltart, Cardiac Department, St. Thomas's Hospital, London SE1 $7 \mathrm{EH}$. 